\title{
The Effect of Cotton Seed Cake, Lucerne Hay Supplementation on Intake of Maize Stover and Weight Gain by Male Sahiwal Bull
}

\section{Khurshaid Anwar}

\author{
Livestock Research \& Development Station Surezai, Peshawar, Pakistan
}

Corresponding author Email: Surezai01@yahoo.com

\begin{abstract}
The experiment was conducted at livestock research and development station surezai Peshawar during March 2012 to study the effect of cotton seed cake, Lucerne hay supplementation on intake of maize stover and weight gain by male sahiwal bull. Twelve (12) young Sahiwal bull breed, $280 \mathrm{~kg}$ average liveweight and 2 years of age were randomly put into 4 groups of 3 animals under intensive feeding system to determine the effect of different protein supplements on growth, and intake of chopped, dried maize stover. A control group was fed stover adlibitum only, and the other groups were fed daily $750 \mathrm{~g}$ cottonseed cake/head, $1 \mathrm{~kg}$ lucerne hay or $900 \mathrm{~g}$ of lucerne/cottonseed cake $(66: 34 ; \mathrm{w} / \mathrm{w})$. Significant differences were observed on average daily live weight gains. Animals on lucerne and its mixture registered higher daily gains $(243 \mathrm{~g})$ and (330 g) respectively, followed by cottonseed cake $(156 \mathrm{~g})$; the control group lost weight $(-8.0 \mathrm{~g} / \mathrm{d})$. Contrary to the live weight gains, animals fed on lucerne and its mixture had lower maize stover intakes, $3.35 \mathrm{~kg} \mathrm{DM} / \mathrm{animal} /$ day and $3.70 \mathrm{~kg} \mathrm{DM}$ respectively, while those on cottonseed cake and the control group ingested respectively $4.72 \mathrm{~kg} \mathrm{DM}$ and $4.16 \mathrm{~kg}$ DM maize Stover. It is concluded that during the critical period in the suburb of Peshawar, small-scale farmers can prevent loss in live weight by utilizing simple available rations.
\end{abstract}

Key words: livestock; stover; lucerne; maize; bull; animals; dry matter; protein; cottonseed

\section{Introduction}

Due to lack of recommended beef breed in Pakistan, people mostly generate revenue to alleviate their poverty by rearing and selling sahiwal male for meat purposes. In southern Peshawar small-scale farmers practice mixed farming. Animals, especially ruminants, lose 20 to 30 percent of their liveweight during the dry season due to low productivity of pasture (Hoste 1974). But the use of concentrate supplements, or the chemical, physical and microbial treatments generally recommended (Nicholson 1981; Hartley 1981) to improve the low energy and protein in lignified straw are not actually applicable to small scale farmers however historical perspective, when Oklahoma researchers (Hibberd et al., 1987) added increasing levels of cotton seed meal to low-quality native grass hay diets containing equal amounts of corn, they observed a significant improvement in digestibility. Several growth trials have supported these results through comparable performance using either hay-based or silage-based diets (Brown, 1991).

. There is a great need to prevent weight loss by using simple techniques and readily available rations.

A study was therefore undertaken to evaluate the effect of different protein supplements on the growth and feed intake of young bulls fed intensively on chopped dried maize stover. 


\section{Materials and methods}

\section{Experimental location}

The experiment was conducted at livestock research and developmet station surezai Peshawar during March 2012 to study the effect of cotton seed cake, Lucerne hay supplementation on intake of maize stover and weight gain by male sahiwal bull

\section{Animals}

Twelve Sahiwal bulls, of average liveweight $280 \mathrm{~kg}$ and aged 3 years were randomly assigned to 4 groups of 3 animals each. The animals were housed in a roofed, half walled shed with a concrete floor, treated for worms and ectoparasites, and injected with A, D, K, E polyvitamins.

\section{Feed and Feeding}

A two week adaption period of maize stover was followed by a 14 week experimental period during which maize stover was given ad libitum at the rate of $120 \%$ of the intake. The diets were composed of:

basal diet - ad libitum dried chopped maize stover.

diet 1 - basal diet $+750 \mathrm{gm}$ cottonseed cake/animal/day.

diet 2 - basal diet +1000 gm lucerne hay/animal/day

diet 3 - basal diet $+900 \mathrm{gm} /$ day of a mixture of lucerne hay and cottonseed cake in the ratio of $66: 34(\mathrm{w} / \mathrm{w})$.

The supplement was given separately each morning before the basal diet of maize stover. Water and a mineral supplement (50:50 common salt/bone meals) were given separately ad libitum. Chopped maize stover and refusals were weighed each morning. Animals were weighed fortnightly from the beginning of the adaptation period to the end of the experimental period.

The chemical composition of maize stover and lucerne was determined using the methods of Van Soest (1967) for cell wall materials and nitrogen was measured by a Kjeldahl procedure; these figures are shown in Table 1.

Table 1: chemical composition of ration ingredients (\%)

\begin{tabular}{|c|c|c|c|c|c|c|c|c|}
\hline Particulars & $\begin{array}{l}\text { Dry } \\
\text { Matter }\end{array}$ & $\begin{array}{l}\text { Crude } \\
\text { Protein }\end{array}$ & Cellulose & Hemicellulose & NDF & ADF & Lignin & Ash \\
\hline $\begin{array}{l}\text { Crude protein } \\
\text { in daily } \\
\text { supplements } \\
\text { fed }\end{array}$ & \multicolumn{2}{|c|}{ Basal diet } & \multicolumn{2}{|l|}{ Diet 1} & \multicolumn{2}{|l|}{ Diet 2} & \multicolumn{2}{|l|}{ Diet 3} \\
\hline $\begin{array}{l}\text { Cottonseed } \\
\text { cake }\end{array}$ & 88.60 & 34.05 & & & & & & \\
\hline Lucerne hay & 89.05 & 25.53 & 8.60 & 12.76 & 22.22 & 34.99 & 12.76 & 14.56 \\
\hline \multirow[t]{2}{*}{ Maiza Stover } & 92.05 & 4.05 & 29.20 & 19.50 & 42.60 & 62.10 & 12.50 & 9.50 \\
\hline & \multicolumn{2}{|l|}{0} & \multicolumn{2}{|l|}{255.37} & \multicolumn{2}{|c|}{255.30} & \multicolumn{2}{|l|}{255.84} \\
\hline
\end{tabular}


Liveweight gains and feed intake were submitted to analysis of variance and Fisher's test was applied to determine significant differences among treatments.

\section{Results and discussion}

Intakes of maize stover and liveweights are given in table 2. Cottonseed cake slightly but nonsignificantly increased maize stover intake, but both lucerne and lucerne/cottonseed mixture reduced maize stover intake significantly $(\mathrm{P}<0.5)$.

Table 2. Effects of diets 1, 2 and 3 on dry matter intake of maize stover and on liveweight gains in cattle over an experimental period of 12 weeks.

\begin{tabular}{|l|l|l|l|l|}
\hline Rations Parameter & Basal Diet & Diet 1 & Diet 2 & Diet 3 \\
\hline No. of animals & 3 & 3 & 3 & 3 \\
\hline Liveweight $(\mathrm{kg})$ & & & & \\
\hline \multicolumn{1}{|l}{ - initial } & 275 & 277 & 276 & 277 \\
\hline \multicolumn{1}{|l}{ - final } & 274 & 291 & 298 & 308 \\
\hline LWG $(\mathrm{g}) /$ day & $-8^{\mathrm{a}}$ & $154^{\mathrm{b}}$ & $236^{\mathrm{c}}$ & $325^{\mathrm{d}}$ \\
\hline Daily maize stover intake $\mathrm{kg} \mathrm{DM} /$ animal & $4.16^{\mathrm{a}}$ & $4.72^{\mathrm{a}}$ & $3.25^{\mathrm{a}}$ & $3.70^{\mathrm{b}}$ \\
\hline
\end{tabular}

$\mathrm{a}, \mathrm{b}$ Means in the same row not having common letters differ significantly $(\mathrm{P}<0.05)$.

Table 2 shows that the liveweight gains (LWG) of the supplemented groups differed significantly from each other, and all significantly exceeded that from the basal diet of maize stover, which produced weight loss (-8 g/animal/day). In terms of LWG, Lucerne hay alone was more effective for animals than cottonseed cake alone. Animals supplemented with the mixture of lucerne hay and cottonseed cake registered the highest LWG, showing the mixed supplement to have been more beneficial for cattle growth than either supplement alone. In the three supplemented groups, the quantity of supplementary protein was the same, and thus LWG was significantly affected by the source of supplementary protein.

(Cao et al., 2008) observed Cows fed long Lucerne (LL) hay spent more time ruminating compared with cows fed short lucerne (SL) hay ranging from 293 to $336 \mathrm{~min} /$ day (p $<0.001$ ). Total time spent chewing by cows increased from 505 to $574 \mathrm{~min} /$ day $(\mathrm{p}=0.002)$ for SL and LL respectively. Based on the results from this study, midlactation cows can be fed diets that contain ground maize grain and SL hay without leading to negative effects on ruminal $\mathrm{pH}$ and nutrient digestibility, these findings are in line with our research findings.

Morgan (1977) observed in sheep that finely ground cottonseed meal provided animals with by-pass protein resulting in increased total feed intake. The low voluntary intake of maize stover could be the result both of low crude protein content and low digestibility (Finn 1976), in turn probably related to its high lignin content (12\%) which limits the fermentable energy available (Lindberg et al., 1984).

While both leucaena hay alone and its mixture with cotton seed cake significantly decreased maize stover intake, the effect of leucaena alone was relatively more pronounced. This might have been due either to its lignin content ( $12 \%$ as in corn stover) or to the toxic effect of mimosine (Jones et al., 1983) which was not assessed, but in view of the gains observed, probably unimportant 


\section{Conclusions}

It is concluded that small-scale farmers could avoid animal weight loss during the critical period of the year by using small quantities of higher quality supplements, and consequently reduce animal mortality and weakness due to malnutrition.

\section{References}

Brown, W.F. 1991. Molasses and cottonseed meal supplementation of ammoniated hay for yearling cattle. In: Florida Beef Cattle Res. Rep. p. 63.

Cao Z.J., Li S.L. Xing j.j. Ma M. and Wang L.L. 2008. Effects of maize grain and lucerne particle size on ruminal fermentation, digestibility and performance of cows in midlactation. Journal of Animal Physiology Animal Nutrition (Berl) 92 (2): 157-67

Finn R. 1979. Low quality forages improve with alkali treatment. Feedstuffs, October 15, Biotechnical Institute Kolding, Denmark.

Hartley R.D. 1981. Chemical constitution, properties and processing of lignocellulosic wastes in relation to nutritional quality for animals. Agricultural Environment. 6: 91-115.

Hibberd, C.A., C.C. Chase, Jr., and L.D. Bourquin. 1987. Added cottonseed meal for beef heifers consuming corn-supplemented low-quality native grass hay diets. In: Anim. Sci. Res. Rep., Okla. State Univ. MP-119, p. 275.

Hoste L. 1974. Effet de la saison sèches sur le bovin a viande. Fiche technique, Centre de Recherche Zootechnique de Wakwa, Cameroon.

Jones R.J. 1981. Does ruminal metabolism of mimosine explain the absence of leucaena toxicity in Hawaii. Australian Veterinary Journal, 57: 55-6.

Jones, R. J., and R.G. Megarrity .1983. Comparative toxicity responses of goats fed onLeucaena leucocephala in Australia and Hawaii. Australian Journal of Agricultural Research 34(6) 781 - 790

Leng R.A. and Preston T.R. 1983. Nutritional strategies for the utilization of agro-industrial byproducts by ruminants and extension of the principles and technologies to the small-scale farmer in Asia. Proc. V World Conference on Animal Production, 1: 310-318.

Lindberg E.J., Ternrud E.I. and Theander O. 1984. Degradation rate and chemical composition of different types of alkali-treated straws during rumen digestion. Journal of the Science of Food and Agriculture. 35: 500-506.

Morgan P.J.K. 1977. The flowpaths taken by ground supplements in the stomachs of sheep. South African Journal of Animal Science. 7: 91-95.

NDumbe D.R. 1979. Substitution of maize grain with rice bran in beef cattle diets. Annual Report. Animal Research Centre, Bambui, Cameroon. 
NDumbe D.R. 1980. Optimum level of rice bran in beef cattle rations. Annual Report. Animal Research Centre, Bambui, Cameroon.

NDumbe D.R. and Njoya A. 1982. Value of corn stover in beef cattle rations. Annual Report. Animal Research Centre, Bambui, Cameroon.

NDumbe D.R. and Wegad D. 1984. Optimum levels of corn stover in beef cattle rations. Annual Report. Animal Research Centre, Bambui, Cameroon.

Nicholson J.W.G. 1981. Nutrition and feeding aspects of the utilization of processed lignocellulosic waste materials by animals. Agricultural Environment. 6: 205-228.

Van Soest, P.J. and Wine R.M. 1987. Use of detergent in the analysis of fibrous materials. IV. Determination of plant cell wall constituents. Journal of the Association of Official Agricultural Chemists. 50:50.

VaN Soest, P. J. 1967. Development of a comprehensive sysrem of feed analyses and its application to forages. J. Animal Sci. 26, 179-128 